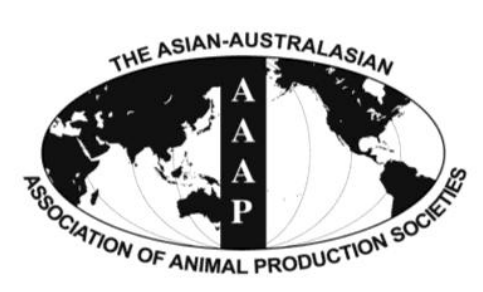

Open Access

Asian Australas. J. Anim. Sci.

Vol. 27, No. 6 : 797-805 June 2014

http://dx.doi.org/10.5713/ajas.2013.13560

www.ajas.info

pISSN 1011-2367 elSSN 1976-5517

\title{
Effect of Crude Protein Levels in Concentrate and Concentrate Levels in Diet on In vitro Fermentation
}

\author{
Dinh Van Dung ${ }^{1,2}$, Weiwei Shang ${ }^{1}$, and Wen Yao ${ }^{1, *}$ \\ ${ }^{1}$ College of Animal Science and Technology, Nanjing Agricultural University, Nanjing 210095, China
}

\begin{abstract}
The effect of concentrate mixtures with crude protein (CP) levels 10\%,13\%, 16\%, and 19\% and diets with roughage to concentrate ratios 80:20, 60:40, 40:60, and 20:80 (w/w) were determined on dry matter (DM) and organic matter (OM) digestibility, and fermentation metabolites using an in vitro fermentation technique. In vitro fermented attributes were measured after 4,24 , and $48 \mathrm{~h}$ of incubation respectively. The digestibility of DM and OM, and total volatile fatty acid (VFA) increased whereas pH decreased with the increased amount of concentrate in the diet $(\mathrm{p}<0.001)$, however CP levels of concentrate did not have any influence on these attributes. Gas production reduced with increased $\mathrm{CP}$ levels, while it increased with increasing concentrate levels. Ammonia nitrogen $\left(\mathrm{NH}_{3}-\mathrm{N}\right)$ concentration and microbial CP production increased significantly $(\mathrm{p}<0.05)$ by increasing CP levels and with increasing concentrate levels in diet as well, however, no significant difference was found between $16 \%$ and $19 \% \mathrm{CP}$ levels. Therefore, $16 \% \mathrm{CP}$ in concentrate and increasing proportion of concentrate up to $80 \%$ in diet all had improved digestibility of DM and organic matter, and higher microbial protein production, with improved fermentation characteristics. (Key Words: In vitro Gas Production, Crude Protein, Roughage to Concentrate Ratio)
\end{abstract}

\section{INTRODUCTION}

In developing countries, low cattle production may be caused by inadequate nutrient supply in a high-forage based ration (Suharti et al., 2011). Therefore, it is essential for cattle production systems to find new sources and technologies of feedstuffs. Recently, smallholder farmers have been using a variety of concentrate ingredients such as rice bran, maize meal and cassava powder as well as concentrate mixture from these concentrate feedstuffs in cattle production (Suharti et al., 2011). However, the benefit of using these available feeds is limited because of insufficient information about nutritive value, digestibility and rumen fermentation characteristics. Previous studies reported that concentrate feeds differ substantially in their

\footnotetext{
* Corresponding Author: Wen Yao. Tel: +86-25-84395523, Fax: +86-25-84395314, E-mail: yaowen67jp@njau.edu.cn

${ }^{2}$ Department of Technical Education, College of Education, Hue University, Hue city, Vietnam.

Submitted Sept. 11, 2013; Revised Dec. 14, 2013; Accepted Jan. 13, 2014
}

rumen fermentation characteristics (Mills et al., 1999). This may be due to the differences in the physical and chemical characteristics of each concentrate (Ørskov, 1986). Concentrate containing high starch is important in ruminant nutrition because it is a practical and cost-effective source of energy and has been shown to influence the functioning of the rumen and nutrient digestion (Krause and Oetzel, 2006; Tahir et al., 2013).

Nutritive values are an important measure for evaluating ruminant feeds. It can be determined by several methods such as in vivo, in situ, and in vitro techniques. In vivo method is laborious and requires a relatively large number of animals (Zicarelli et al., 2011). While in situ method has the advantage that it uses the actual rumen environment to measure feed digestion, it also has the disadvantage that it is expensive in terms of labour and analytical costs, and measures feed disappearance but not the actual amount of fermented substrate (Tagliapietra et al., 2011), primary and secondary losses of particulate matter as well as the differences between the level of microbial activity inside the in situ bags and that in the rumen (Tahir et al., 2013). 
These factors can result in over-all underestimation of rumen digestibility of nutrients.

The in vitro methods provide less expensive and more rapid alternatives (Getachew et al., 2004), and these techniques have been widely used to assess the nutritive value of feeds not only because these methods are capable of measuring rate and extent of nutrients degradation with less expenditure, but also because DM digestibility and VFA production measured by in vitro gas production techniques highly correspond with data provided by in vivo experiments (Menke and Steingass, 1988; Theodorou et al., 1994; Getachew et al., 2004; Shuharti et al., 2011; Tahir et al., 2013). However, all the above authors used mainly a single feedstuffs and roughage as substrate for incubation. Few researches used concentrate mixtures or diets with different rations of roughage and concentrate as substrate.

The objective of this study was to evaluate the in vitro characteristics of four concentrate mixtures with four levels of $\mathrm{CP}$, and four diets with different roughage to concentrate ratios.

\section{MATERIALS AND METHODS}

\section{Rumen inoculum}

Rumen fluid was collected before morning feeding from 3 fistulated dry dairy cows fed on grass ad libitum and 2 $\mathrm{kg} / \mathrm{d}$ of concentrate. The rumen fluid was immediately transferred to the laboratory in a warmed thermos flask (39$\pm 0.5^{\circ} \mathrm{C}$ ), and then filtered through 4 layers of cheesecloth to eliminate feed particles and then mixed with the buffer mineral solution in a 1 to 9 ration. All operations were made under anaerobic conditions by flushing with carbon dioxide. Buffer mineral solution according to Theodorou et al. (1994) was preheated in a water bath at $39^{\circ} \mathrm{C}$ and purged continuously with $\mathrm{CO}_{2}$ for $30 \mathrm{~min}$.

\section{Substrates and chemical analyses}

Eight feeds were investigated, including four concentrate mixtures with four levels of CP $(10 \%, 13 \%$, $16 \%$, and 19\%), and four mixed feeds with different roughage to concentrate (16\% CP) ratios (80:30, 60:40, 40:60, and 20:80 w/w). Feed samples were grounds to pass a $1 \mathrm{~mm}$ sieve using a hammer mill (Pullerisette 19, Fritsch $\mathrm{GmbH}$, Laborgeratebau, Germany) and analyzed for their chemical composition. DM, ash and nitrogen $(\mathrm{N})$ level using standard methods of AOAC (1990) after drying at $60^{\circ} \mathrm{C}$. The concentration of $\mathrm{CP}$ was calculated as $\mathrm{N} \times 6.25$. The GE of feeds were determined by bomb calorimetry (Bomb Calorimeter 6300, Parr Instrument Company, Moline, IL, USA), and NDF was determined according to the method of Van Soest et al. (1991) with addition of $\alpha$ amylase but without sodium sulphite and results expressed with residual ash. Table 1 presents the feed ingredients and nutrient composition investigated in this experiment.

\section{In vitro fermentation and fermentation attributes analyses \\ One $\pm 0.001 \mathrm{~g}$ of the air dried feeds was incubated in 160}

Table 1. Ingredient and composition of feeds used for in vitro fermentation

\begin{tabular}{|c|c|c|c|c|c|c|c|c|}
\hline \multirow{2}{*}{ Items } & \multicolumn{4}{|c|}{$\mathrm{CP}$ levels in concentrate $(\%)$} & \multirow{2}{*}{\multicolumn{4}{|c|}{ Roughage to concentrate ratios }} \\
\hline & 10 & 13 & 16 & 19 & & & & \\
\hline \multicolumn{9}{|l|}{ Ingredient (\% fresh basis) } \\
\hline Rice straw & & & & & 80 & 60 & 40 & 20 \\
\hline Concentrate $^{1}$ & & & & & 20 & 40 & 60 & 80 \\
\hline Rice bran & 35.0 & 33.0 & 33.0 & 33.0 & & & & \\
\hline Maize & 32.5 & 30.0 & 30.0 & 30.0 & & & & \\
\hline Cassava powder & 30.0 & 29.0 & 25.0 & 17.0 & & & & \\
\hline Fish meal & 0.0 & 5.0 & 8.5 & 16.5 & & & & \\
\hline Urea & 0.5 & 1.0 & 1.5 & 1.5 & & & & \\
\hline Salt & 1.0 & 1.0 & 1.0 & 1.0 & & & & \\
\hline Premix vitamin-mineral $^{2}$ & 1.0 & 1.0 & 1.0 & 1.0 & & & & \\
\hline \multicolumn{9}{|c|}{ Chemical composition (\% DM) } \\
\hline $\mathrm{DM}$ & 87.3 & 89.5 & 89.3 & 88.6 & 89.7 & 89.6 & 89.5 & 89.4 \\
\hline $\mathrm{OM}$ & 94.6 & 93.5 & 91.7 & 89.2 & 88.0 & 88.9 & 89.9 & 90.8 \\
\hline $\mathrm{CP}$ & 10.1 & 13.2 & 16.9 & 20.2 & 7.53 & 9.86 & 12.2 & 14.6 \\
\hline NDF & 21.8 & 19.2 & 22.9 & 18.4 & 62.8 & 52.8 & 42.9 & 32.9 \\
\hline Ash & 5.5 & 6.5 & 8.3 & 10.8 & 12.0 & 11.1 & 10.1 & 9.2 \\
\hline GE (MJ/kg DM) & 18.1 & 18.1 & 18.1 & 18.1 & 17.6 & 17.7 & 17.9 & 18.0 \\
\hline
\end{tabular}

${ }^{1}$ Concentrate consisting of $33 \%$ rice bran, $30 \%$ maize meal, $25 \%$ cassava powder, $8.5 \%$ fish meal, $1.5 \%$ urea, $1 \%$ salt, and $1 \%$ premix vitamin-mineral.

${ }^{2}$ Premix vitamin-mineral (per kg): 3,600,000 UI vitamin A; 300,000 UI vitamin $\mathrm{D}_{3} ; 4,000 \mathrm{mg}$ vitamin E; $500 \mathrm{mg}$ vitamin $\mathrm{B}_{1} ; 1,000 \mathrm{mg}$ vitamin $\mathrm{B}_{2} ; 650$ $\mathrm{mg}$ vitamin $\mathrm{B}_{6} ; 6 \mathrm{mg}$ vitamin $\mathrm{B}_{12} ; 12,000 \mathrm{mg}$ vitamin $\mathrm{C} ; 300 \mathrm{mg}$ vitamin $\mathrm{K}_{3} ; 16 \mathrm{mg}$ biotin; $100 \mathrm{mg}$ folic acid; 2,500 mg vitamin $\mathrm{B}_{5} ; 5,000 \mathrm{mg}$ niacin; 40,000 mg Cholin chloride (Fe, Zn, Cu, Mn, Mg). 
$\mathrm{mL}$ bottle which containing $90 \mathrm{~mL}$ of buffer mineral solution and $10 \mathrm{~mL}$ of rumen fluid (Theodorou et al., 1994) for $48 \mathrm{~h}$ at $39^{\circ} \mathrm{C}$. During the incubation, the cumulative gas production was measured at 2, 4, 6, 8, 12, 18, 24, 30, 36, and $48 \mathrm{~h}$ using a manual pressure transducer (Theodorou et al., 1994).

Digestibility of DM and OM, pH, VFA production, microbial $\mathrm{CP}$ and $\mathrm{NH}_{3}-\mathrm{N}$ concentration were determined at three time points (4, 24, and $48 \mathrm{~h}$ after incubation). Each time, $\mathrm{pH}$ value was measured immediately by $\mathrm{pH}$ meter (Schott, Germany), and then approximately $10 \mathrm{~mL}$ of end liquids were sampled and divided into aliquots for downstream analyses, including VFA production, $\mathrm{NH}_{3}-\mathrm{N}$ concentration after being equally mixed with $0.2 \mathrm{M} \mathrm{HCl}$ and microbial CP. The rest of end liquids in each bottle were centrifuged at $10,000 \times \mathrm{g}$ for $5 \mathrm{~min}$, supernatant removed and dried at $105^{\circ} \mathrm{C}$ for $12 \mathrm{~h}$ and burning at $550^{\circ} \mathrm{C}$ for $4 \mathrm{~h}$ to determine DM and ash. Digestibility of DM and $\mathrm{OM}$ were calculated as difference weighing between before and after incubation, corrected by a blank which consisted of four flask containing only buffered rumen fluid.

To analyse VFA production, $0.2 \mathrm{~mL}$ of metaphosphoric crotonic sodium was added to $1 \mathrm{~mL}$ of end fermented liquid and stored at $-20^{\circ} \mathrm{C}$ overnight, and then centrifuged twice at $12,000 \mathrm{rpm}$ for $10 \mathrm{~min}$ at $4^{\circ} \mathrm{C}$. VFAs were measured by gas chromatography using a fused silica capillary column (30 $\mathrm{m} \times 0.25 \mathrm{~mm}, 0.25 \mathrm{~mm}$ film thickness). Pure chemicals of acetate, propionate and butyrate purchased from SigmaAldrich were used as external standards. The area of each VFA response was compared with those of the external standards (Zicarelli et al., 2011).

For $\mathrm{NH}_{3}-\mathrm{N}$ concentration, $1 \mathrm{~mL}$ of end liquid preserved by $0.2 \mathrm{M} \mathrm{HCl}$ was firstly centrifuged at $12,000 \mathrm{rpm}$ for 15 min at $7^{\circ} \mathrm{C}$, then $0.01 \mathrm{~mL}$ of supernatant was transferred into a new tube, and $2.5 \mathrm{~mL}$ of phenol color reagent and 2.0 $\mathrm{mL}$ of hypochlorite reagent sodium were added. $\mathrm{NH}_{3}-\mathrm{N}$ concentration was measured by reading absorbance at 630 nanometers using spectrophotometer. The concentration of $\mathrm{NH}_{3}-\mathrm{N}$ is directly proportional to the absorbance of indophenol which is measured.

For microbial $\mathrm{CP}$ determination, $3 \mathrm{~mL}$ of subsample was centrifuged at $1,000 \mathrm{rpm}$ for $8 \mathrm{~min}$ at $4^{\circ} \mathrm{C}$, then $1 \mathrm{~mL}$ of supernatant was collected and centrifuged at 15,000 rpm for $15 \mathrm{~min}$ at $4^{\circ} \mathrm{C}$, the supernatant was discarded, $3 \mathrm{~mL}$ of $\mathrm{NaOH} 0.25 \mathrm{~N}$ was added and heated in boiling water bath for $10 \mathrm{~min}$. Contents then were centrifuged at $15,000 \mathrm{rpm}$ for $30 \mathrm{~min}$ at $4^{\circ} \mathrm{C}$, and $0.2 \mathrm{~mL}$ of supernatant was collected and $5 \mathrm{~mL}$ of coomasie brilliant blue G-250 dye was added to recovered protein. Microbial $\mathrm{CP}$ of $0.2 \mathrm{~mL}$ was determined by absorbance on a plate reader at 595 nanometers. Precipitated bovine serum albumin was standard sodium (Martin and Martin, 1982).

\section{Statistical analysis}

Data were analyzed using the GLM procedure of SPSS 16.0. The following model wasused to determine treatment mean differences using a least significant difference method:

$$
Y_{i j}=\mu+S_{i}+e_{i j}
$$

Where $Y_{i j}$ is the observation from bottle $\mathrm{j}$, feed $\mathrm{i} ; \mu$ is the overall of mean; $S_{i}$ is the effect of feeds and $e_{i j}$ is the residual effect. Polynomial contrasts were used to determine linear and quadratic effects of CP levels and concentrate levels on dependent variables. In all the analyses, significant effects were declared at $\mathrm{p}<0.05$.

\section{RESULTS}

\section{Chemical composition, gas production, and apparent in vitro $\mathrm{DM}$ and $\mathrm{OM}$ digestibility}

The ingredient and chemical composition of feeds used in this experiment are presented in Table 1. The OM contents in feeds was variable, as the lowest to be in mixed feed with 80:20 of roughage to concentrate ratio and the highest in concentrate mixture with $10 \%$ of $\mathrm{CP}$ content. The CP content varied from $7.53 \%$ to $20.2 \%$. The higher value for NDF was observed in mixed feeds instead of concentrate mixture.

The patterns of cumulative gas production of various feeds are presented in Figure 1. For concentrate mixtures, the cumulative gas production over $48 \mathrm{~h}$ was negatively correlated with their CP levels (Figure 1a). While for mixed feeds with ratios of roughage to concentrate, in vitro fermentation was faster with an increasing proportion of concentrate in diet (Figure 1b).

Increasing CP levels in concentrate had no significant effect $(p>0.05)$ on DM and OM digestibility, whereas increasing the proportion of concentrate resulted in raised $(\mathrm{p}<0.001) \mathrm{DM}$ and OM digestibility (Table 2).

\section{$\mathrm{pH}, \mathrm{NH}_{3}-\mathrm{N}$ concentration and microbial $\mathrm{CP}$}

For concentrate mixtures with different $\mathrm{CP}$ levels, there was no significant affect $(\mathrm{p}>0.05)$ on $\mathrm{pH}$ at different incubation periods, whereas $\mathrm{NH}_{3}-\mathrm{N}$ concentration and microbial $\mathrm{CP}$ were significantly affected $(\mathrm{p}<0.05)$ by $\mathrm{CP}$ levels (Table 3). However, no significant difference was found ( $p>0.05$ ) between $16 \%$ and $19 \%$ CP in concentrate.

For mixed feeds with different ratios of roughage to concentrate, there were significant affects $(\mathrm{p}<0.05)$ on $\mathrm{NH}_{3}$ $\mathrm{N}$ concentration, $\mathrm{pH}$ during incubation time and microbial $\mathrm{CP}$. The $\mathrm{pH}$ value decreased, whereas $\mathrm{NH}_{3}-\mathrm{N}$ and microbial $\mathrm{CP}$ concentration increased linearly with increasing concentrate in diet (Table 3). 

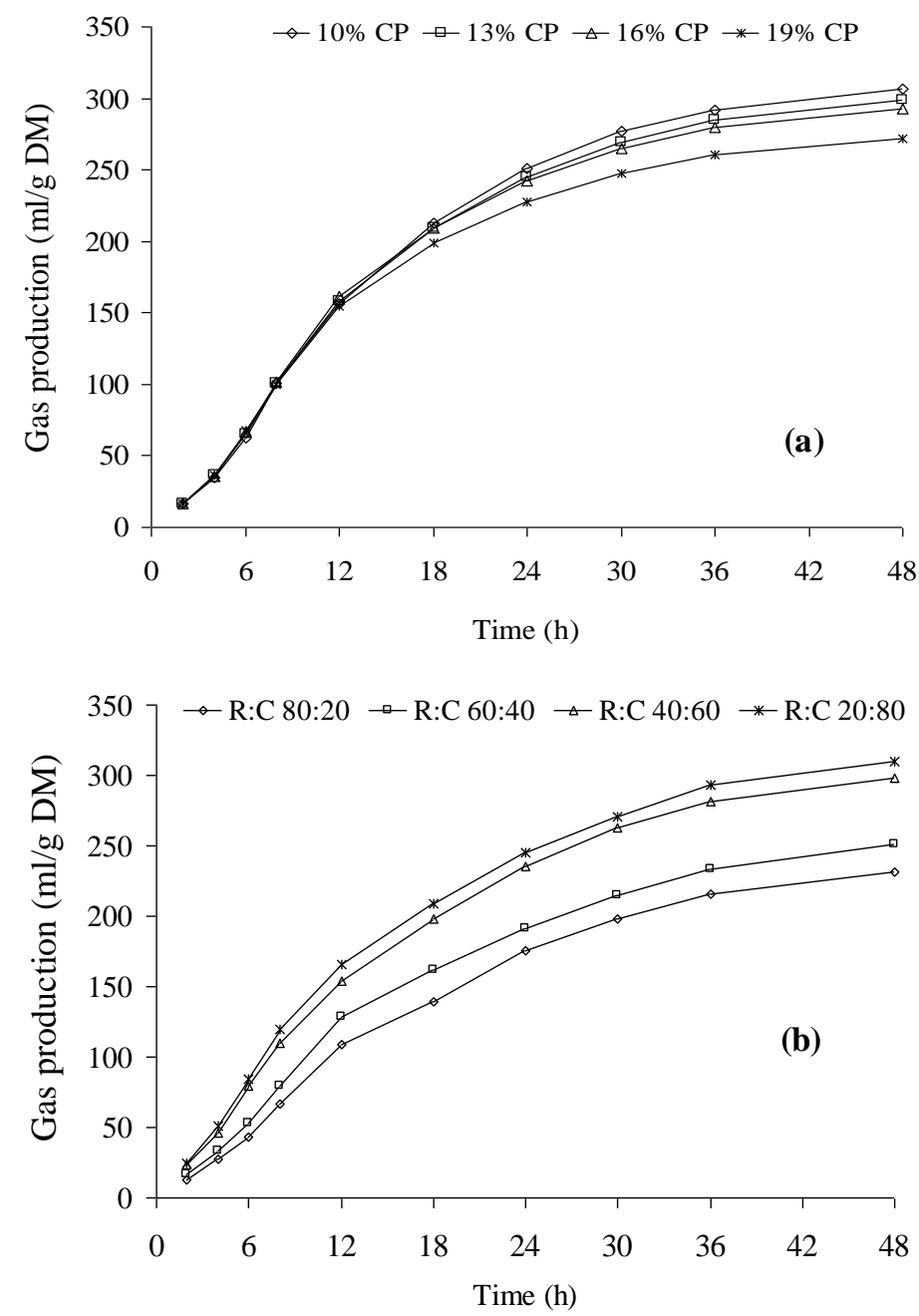

Figure 1. In vitro gas production for different CP levels in concentrate (a) and different roughage to concentrate ratios (b) incubated with rumen fluid.

\section{Volatile fatty acid}

For concentrates with different $\mathrm{CP}$ levels, there was no significant affect $(p>0.05)$ on the total VFA and molar proportion of individual VFA production. A significant effect $(\mathrm{p}<0.05)$ on acetate to propionate ratio at $24 \mathrm{~h}$ after incubation was discernible between treatments (Table 4).

For mixed feeds with different ratios of roughage to concentrate, there was a significant affect on $(p<0.05)$ total VFA production and which increased linearly with an increasing proportion of concentrate. However, the proportion of individual VFA did not vary significantly with roughage to concentrate ratios $(\mathrm{p}>0.05)$, except for the proportion of acetate at $24 \mathrm{~h}$ incubation. Acetate to propionate ratios were comparable $(p>0.05)$ among roughage and concentrate ratios (Table 5).

\section{DISCUSSION}

Our results indicated that increasing $\mathrm{CP}$ in concentrate leads to less gas production, while raising the proportion of concentrate in diet leads to more gas production. The negative relationship between $\mathrm{CP}$ content of the substrate and gas production has already been shown in several researches (Rodríguez et al., 2010; Soltan et al., 2012), while the positive relationship between gas production rate and amount of concentrate in diet has also been confirmed by previous reports (Bannink et al., 2000; Zicarelli et al., 2011). The higher energy available for microbial populations supplied by the higher concentrate could offer an explanation for this observation. On the other hand, increasing concentrate in diet reduced NDF content, which factors into increase of gas production (Rodríguez et al., 2010; Zicarelii et al., 2011; Soltan et al., 2012). However, the total amount of gas production during in vitro fermentation is obtained when the fermentation of various substances occurred at the same time. Due to the different speed of fermentation of different substances in such a process, it is difficult to relate every affected division to 
Table 2. Apparent in vitro DM and OM digestibility of level of CP in concentrate and concentrate levels

\begin{tabular}{|c|c|c|c|c|c|c|}
\hline \multirow{2}{*}{ Feeds } & \multicolumn{3}{|c|}{ DM digestibility (\%) } & \multicolumn{3}{|c|}{ OM digestibility (\%) } \\
\hline & $4 \mathrm{~h}$ & $24 \mathrm{~h}$ & $48 \mathrm{~h}$ & $4 \mathrm{~h}$ & $24 \mathrm{~h}$ & $48 \mathrm{~h}$ \\
\hline \multicolumn{7}{|c|}{$\overline{\mathrm{CP}}$ level in concentrate (\%) } \\
\hline 10 & 18.5 & 64.6 & 80.8 & 21.4 & 66.7 & 81.5 \\
\hline 13 & 18.8 & 63.7 & 81.2 & 19.3 & 66.5 & 81.4 \\
\hline 16 & 20.3 & 65.6 & 81.1 & 20.4 & 67.1 & 81.2 \\
\hline 19 & 20.7 & 66.3 & 78.7 & 20.9 & 66.7 & 79.2 \\
\hline SEM & 0.68 & 1.03 & 0.82 & 1.14 & 1.02 & 0.81 \\
\hline \multicolumn{7}{|l|}{ Contrast $^{\mathrm{e}}$} \\
\hline $\mathrm{L}$ & ns & ns & ns & ns & ns & ns \\
\hline Q & ns & ns & ns & ns & ns & ns \\
\hline \multicolumn{7}{|c|}{ Roughage to concentrate ratios } \\
\hline $80: 20$ & $15.0^{\mathrm{a}}$ & $52.5^{\mathrm{a}}$ & $60.3^{\mathrm{a}}$ & $15.1^{\mathrm{a}}$ & $53.0^{\mathrm{a}}$ & $60.7^{\mathrm{a}}$ \\
\hline $60: 40$ & $17.2^{\mathrm{b}}$ & $58.5^{\mathrm{b}}$ & $67.8^{\mathrm{b}}$ & $18.8^{\mathrm{b}}$ & $59.2^{\mathrm{b}}$ & $68.1^{\mathrm{b}}$ \\
\hline $40: 60$ & $19.0^{\mathrm{bc}}$ & $61.1^{\mathrm{b}}$ & $73.7^{\mathrm{c}}$ & $20.8^{\mathrm{b}}$ & $62.1^{\mathrm{b}}$ & $74.2^{\mathrm{c}}$ \\
\hline $20: 80$ & $20.4^{c}$ & $65.4^{\mathrm{c}}$ & $77.8^{\mathrm{d}}$ & $21.0^{\mathrm{b}}$ & $65.4^{\mathrm{c}}$ & $78.1^{\mathrm{d}}$ \\
\hline SEM & 0.67 & 1.24 & 0.47 & 0.83 & 1.31 & 0.51 \\
\hline \multicolumn{7}{|l|}{ Contrast } \\
\hline $\mathrm{L}$ & $* * *$ & $* * *$ & $* * *$ & $* * *$ & $* * *$ & $* * *$ \\
\hline Q & ns & ns & $* *$ & ns & ns & $* *$ \\
\hline
\end{tabular}

$\overline{a, b, c, d}$ Values within a column with different superscript letters are significantly different $(\mathrm{p}<0.05)$.

${ }^{\mathrm{e}} \mathrm{L}$, linear; $\mathrm{Q}$, quadratic; $\mathrm{ns}=$ non-significant. $* * \mathrm{p}<0.01$, *** $\mathrm{p}<0.001$.

each specific factor (Thang et al., 2011).

The results also showed that increasing $\mathrm{CP}$ level in concentrate had no significant effect on in vitro DM and OM digestibility. These observations are in agreement with previous in vivo reports in beef cattle (Chen et al., 2010; Yuangklang et al., 2010) and dairy cows (Ghorbani et al., 2011; Norrapoke et al., 2012). However, the present results did not agree with other researches of cattle (Paengkoum and Tatsapong, 2009) and buffalo (Shahzad et al., 2011; Chanthakhoun et al., 2012). These variations indicated that the effects of $\mathrm{CP}$ levels on the digestibility of nutrients varied and depended on factors such as levels and sources of protein (Milis and Liamadis, 2007; Chantiratikul et al., 2009). In vitro DM and OM digestibility rose as concentrate

Table 3. $\mathrm{pH}, \mathrm{NH}_{3}-\mathrm{N}$ concentration $(\mathrm{mg} / 100 \mathrm{~mL})$ and microbial $\mathrm{CP}(\mathrm{mg} / 100 \mathrm{~mL})$ at 4,24 , and $48 \mathrm{~h}$ after incubation

\begin{tabular}{|c|c|c|c|c|c|c|c|c|c|}
\hline \multirow{2}{*}{ Feeds } & \multicolumn{3}{|c|}{$\mathrm{pH}$} & \multicolumn{3}{|c|}{$\mathrm{NH}_{3}-\mathrm{N}$} & \multicolumn{3}{|c|}{ Microbial CP } \\
\hline & $4 \mathrm{~h}$ & $24 \mathrm{~h}$ & $48 \mathrm{~h}$ & $4 \mathrm{~h}$ & $24 \mathrm{~h}$ & $48 \mathrm{~h}$ & $4 \mathrm{~h}$ & $24 \mathrm{~h}$ & $48 \mathrm{~h}$ \\
\hline \multicolumn{10}{|c|}{ CP levels in concentrate $(\%)$} \\
\hline 10 & 6.61 & 6.25 & 6.06 & $6.94^{\mathrm{a}}$ & $11.9^{\mathrm{a}}$ & $13.0^{\mathrm{a}}$ & $4.67^{\mathrm{a}}$ & $11.2^{\mathrm{a}}$ & $12.1^{\mathrm{a}}$ \\
\hline 13 & 6.67 & 6.27 & 6.09 & $7.15^{\mathrm{a}}$ & $13.2^{\mathrm{b}}$ & $15.5^{\mathrm{b}}$ & $5.19^{\mathrm{a}}$ & $11.3^{\mathrm{b}}$ & $12.4^{\mathrm{a}}$ \\
\hline 16 & 6.60 & 6.20 & 6.06 & $8.11^{\mathrm{b}}$ & $15.7^{\mathrm{c}}$ & $20.3^{c}$ & $5.81^{\mathrm{b}}$ & $12.2^{\mathrm{b}}$ & $13.6^{\mathrm{b}}$ \\
\hline 19 & 6.65 & 6.20 & 6.06 & $8.50^{\mathrm{b}}$ & $15.8^{\mathrm{c}}$ & $20.9^{c}$ & $5.97^{\mathrm{b}}$ & $12.2^{\mathrm{b}}$ & $13.7^{\mathrm{b}}$ \\
\hline SEM & 0.02 & 0.02 & 0.01 & 0.18 & 0.17 & 0.58 & 0.17 & 0.17 & 0.12 \\
\hline \multicolumn{10}{|l|}{ Contrast $^{\mathrm{d}}$} \\
\hline $\mathrm{L}$ & ns & $\mathrm{ns}$ & ns & $* * *$ & $* * *$ & $* * *$ & $* * *$ & $* *$ & $* * *$ \\
\hline Q & ns & ns & ns & ns & $* *$ & ns & ns & ns & ns \\
\hline \multicolumn{10}{|c|}{ Roughage to concentrate ratios } \\
\hline $80: 20$ & $6.77^{\mathrm{a}}$ & $6.30^{\mathrm{a}}$ & $6.16^{\mathrm{a}}$ & $5.26^{\mathrm{a}}$ & $11.2^{\mathrm{a}}$ & $13.4^{\mathrm{a}}$ & $4.58^{\mathrm{a}}$ & $8.07^{\mathrm{a}}$ & $10.9^{\mathrm{a}}$ \\
\hline $60: 40$ & $6.75^{\mathrm{a}}$ & $6.28^{\mathrm{ab}}$ & $6.14^{\mathrm{a}}$ & $6.29^{\mathrm{b}}$ & $12.3^{\mathrm{ab}}$ & $15.1^{\mathrm{ab}}$ & $5.38^{\mathrm{b}}$ & $8.72^{\mathrm{a}}$ & $11.0^{\mathrm{a}}$ \\
\hline $40: 60$ & $6.73^{b}$ & $6.21^{b c}$ & $6.11^{\mathrm{b}}$ & $6.51^{\mathrm{b}}$ & $13.3^{\mathrm{b}}$ & $16.7^{b}$ & $5.51^{\mathrm{b}}$ & $9.26^{\mathrm{a}}$ & $11.9^{b}$ \\
\hline $20: 80$ & $6.66^{c}$ & $6.19^{c}$ & $6.08^{c}$ & $7.20^{\mathrm{c}}$ & $15.8^{\mathrm{c}}$ & $20.1^{\mathrm{c}}$ & $5.77^{\mathrm{c}}$ & $11.4^{\mathrm{b}}$ & $13.0^{\mathrm{c}}$ \\
\hline SEM & 0.01 & 0.03 & 0.01 & 0.14 & 0.56 & 0.56 & 0.10 & 0.48 & 0.14 \\
\hline \multicolumn{10}{|l|}{ Contrast } \\
\hline $\mathrm{L}$ & $* * *$ & $* *$ & $* * *$ & $* * *$ & $* * *$ & $* * *$ & $* * *$ & $* * *$ & $* * *$ \\
\hline Q & $* * *$ & ns & ns & $\mathrm{ns}$ & ns & $\mathrm{ns}$ & ns & $\mathrm{ns}$ & $* *$ \\
\hline
\end{tabular}

\footnotetext{
${ }_{\mathrm{a}, \mathrm{b}, \mathrm{c}}$ Values within a column with different superscript letters are significantly different $(\mathrm{p}<0.05)$.
}

${ }^{\mathrm{d}} \mathrm{L}$, linear; Q, quadratic; ns, non-significant. $* * \mathrm{p}<0.01$, *** $\mathrm{p}<0.001$. 
Table 4. Volatile fatty acid (VFA) at 4, 24, and $48 \mathrm{~h}$ after incubation of concentrate mixtures with different CP level

\begin{tabular}{|c|c|c|c|c|c|c|c|}
\hline \multirow{2}{*}{ Items } & \multicolumn{4}{|c|}{ CP levels in concentrate (\%) } & \multirow{2}{*}{ SEM } & \multicolumn{2}{|c|}{ Contrast $^{\mathrm{d}}$} \\
\hline & 10 & 13 & 16 & 19 & & $\mathrm{~L}$ & $\mathrm{Q}$ \\
\hline \multicolumn{8}{|c|}{ Total VFA (mM) } \\
\hline 4 & 22.4 & 23.1 & 23.8 & 22.9 & 0.32 & ns & ns \\
\hline 24 & 62.8 & 62.6 & 63.3 & 62.6 & 1.34 & ns & $\mathrm{ns}$ \\
\hline 48 & 82.0 & 81.5 & 83.2 & 81.7 & 1.36 & ns & $\mathrm{ns}$ \\
\hline \multicolumn{8}{|c|}{ VFA (mM/100 mM) } \\
\hline \multicolumn{8}{|c|}{ Acetate } \\
\hline 4 & 65.5 & 66.6 & 66.4 & 65.4 & 1.64 & ns & ns \\
\hline 24 & 60.4 & 61.4 & 61.2 & 52.6 & 0.53 & ns & ns \\
\hline 48 & 62.8 & 62.9 & 63.2 & 62.6 & 0.49 & ns & $\mathrm{ns}$ \\
\hline \multicolumn{8}{|c|}{ Propionate } \\
\hline 4 & 22.4 & 22.1 & 21.7 & 22.7 & 1.70 & ns & $\mathrm{ns}$ \\
\hline 24 & $25.3^{\mathrm{a}}$ & 25.1 & 23.9 & 23.0 & 1.42 & ns & ns \\
\hline 48 & 20.9 & 20.6 & 19.4 & 19.4 & 0.50 & ns & $\mathrm{ns}$ \\
\hline \multicolumn{8}{|c|}{ Butyrate } \\
\hline 4 & 9.2 & 9.2 & 10.7 & 8.9 & 1.73 & ns & $\mathrm{ns}$ \\
\hline 24 & 12.7 & 11.9 & 12.9 & 12.3 & 0.50 & $\mathrm{~ns}$ & ns \\
\hline 48 & 12.0 & 11.6 & 12.1 & 12.1 & 0.35 & ns & $\mathrm{ns}$ \\
\hline \multicolumn{8}{|c|}{ Acetate/propionate } \\
\hline 4 & 3.0 & 3.1 & 3.1 & 2.9 & 0.17 & ns & $\mathrm{ns}$ \\
\hline 24 & $2.4^{\mathrm{a}}$ & $2.4^{\mathrm{ab}}$ & $2.6^{\mathrm{bc}}$ & $2.7^{\mathrm{c}}$ & 0.05 & $* *$ & $\mathrm{~ns}$ \\
\hline 48 & 3.0 & 3.1 & 3.3 & 3.3 & 0.10 & ns & ns \\
\hline
\end{tabular}

$\overline{a, b, c}$ Values within a row with different superscript letters are significantly different $(\mathrm{p}<0.05)$.

${ }^{\mathrm{d}} \mathrm{L}$, linear; Q, quadratic; ns, non-significant. ** $\mathrm{p}<0.01$.

Table 5. Volatile fatty acid (VFA) at 4, 24, and $48 \mathrm{~h}$ after incubation of roughage to concentrate ratios

\begin{tabular}{|c|c|c|c|c|c|c|c|}
\hline \multirow{2}{*}{ Items } & \multicolumn{4}{|c|}{ Roughage to concentrate ratios } & \multirow{2}{*}{ SEM } & \multicolumn{2}{|c|}{ Contrast $^{\mathrm{c}}$} \\
\hline & $80: 20$ & $60: 40$ & $40: 60$ & $20: 80$ & & $\mathrm{~L}$ & Q \\
\hline \multicolumn{8}{|c|}{ Total VFA (mM) } \\
\hline 4 & $18.9^{\mathrm{a}}$ & $19.2^{\mathrm{a}}$ & $23.1^{\mathrm{b}}$ & $27.6^{\mathrm{c}}$ & 0.42 & $* * *$ & $* * *$ \\
\hline 24 & $46.6^{\mathrm{a}}$ & $50.3^{\mathrm{a}}$ & $56.3^{\mathrm{b}}$ & $61.4^{\mathrm{c}}$ & 1.08 & $* * *$ & $\mathrm{~ns}$ \\
\hline 48 & $68.9^{\mathrm{a}}$ & $71.3^{\mathrm{ab}}$ & $77.8^{\mathrm{bc}}$ & $81.1^{\mathrm{c}}$ & 2.36 & $* *$ & $\mathrm{~ns}$ \\
\hline \multicolumn{8}{|c|}{ VFA (mM/100 mM) } \\
\hline \multicolumn{8}{|c|}{ Acetate } \\
\hline 4 & 65.6 & 64.5 & 64.9 & 65.3 & 0.90 & $\mathrm{~ns}$ & $\mathrm{~ns}$ \\
\hline 24 & $66.2^{\mathrm{a}}$ & $66.0^{\mathrm{a}}$ & $66.4^{\mathrm{a}}$ & $64.4^{\mathrm{b}}$ & 0.48 & $*$ & $\mathrm{~ns}$ \\
\hline 48 & 64.3 & 63.9 & 62.5 & 62.8 & 0.46 & ns & $\mathrm{ns}$ \\
\hline \multicolumn{8}{|c|}{ Propionate } \\
\hline 4 & 22.3 & 22.2 & 22.6 & 23.5 & 1.79 & $\mathrm{~ns}$ & $\mathrm{~ns}$ \\
\hline 24 & 22.6 & 22.3 & 22.2 & 22.5 & 0.38 & ns & $\mathrm{ns}$ \\
\hline 48 & 21.9 & 22.1 & 22.2 & 21.5 & 0.34 & ns & $\mathrm{ns}$ \\
\hline \multicolumn{8}{|c|}{ Butyrate } \\
\hline 4 & 10.0 & 9.9 & 10.0 & 10.1 & 1.69 & ns & $\mathrm{ns}$ \\
\hline 24 & 10.0 & 10.0 & 10.3 & 10.6 & 0.32 & ns & $\mathrm{ns}$ \\
\hline 48 & 10.3 & 10.3 & 10.5 & 10.4 & 0.41 & ns & ns \\
\hline \multicolumn{8}{|c|}{ Acetate:propionate } \\
\hline 4 & 3.02 & 2.99 & 2.90 & 2.73 & 0.23 & ns & $\mathrm{ns}$ \\
\hline 24 & 2.93 & 2.96 & 2.99 & 2.87 & 0.05 & ns & $\mathrm{ns}$ \\
\hline 48 & 2.94 & 2.89 & 2.82 & 2.93 & 0.06 & ns & ns \\
\hline
\end{tabular}

${ }_{\mathrm{a}, \mathrm{b}}$ Values within a row with different superscript letters are significantly different $(\mathrm{p}<0.05)$.

${ }^{\mathrm{c}} \mathrm{L}$, linear, Q, quadratic; ns, non-significant. * $\mathrm{p}<0.05$, ** $\mathrm{p}<0.01$, *** $\mathrm{p}<0.001$ 
increased, which agrees with results from Kumar et al. (2013). That the higher concentrate level in diets contributed to a higher level of soluble substrates could be the reason for improving $\mathrm{DM}$ and $\mathrm{OM}$ digestibility. In present study, DM and OM digestibility trended to the highest level at $80 \%$ concentrate in diet treatment, which indicated that, increase in concentrate up to $80 \%$ in diet could improve nutrient digestibility.

It also showed that increasing in $\mathrm{CP}$ levels could raise the $\mathrm{NH}_{3}-\mathrm{N}$ concentration. The difference in $\mathrm{NH}_{3}-\mathrm{N}$ concentration may be related directly to $\mathrm{CP}$ concentration and degradability of protein in concentrate. These observations were similar to previous in vivo studies, which reported that $\mathrm{NH}_{3}-\mathrm{N}$ concentration rose with an increasing level of CP (Chen et al., 2010; Ghorbani et al., 2011). Similarly, several authors (Pina et al., 2009; Agle et al., 2010) suggested that $\mathrm{NH}_{3}-\mathrm{N}$ concentration was significantly affected by changing levels of concentrate. The levels of $\mathrm{NH}_{3}-\mathrm{N}$ concentration in the present study were above 5 $\mathrm{mg} / 100 \mathrm{~mL}$, which is required to support maximum growth rate of rumen bacteria for the optimal fermentation and maximized OM digestion in the rumen (McDonald et al., 1995). Values of microbial CP concentration in our study were lower than $\mathrm{NH}_{3}-\mathrm{N}$ concentration. This would indicate that protein degradation is more than synthesis. This finding was similar to that by Chantiratikul et al. (2009) and Chumpawadee et al. (2009). The $\mathrm{pH}$ value measurement can be used as a tool to evaluate the fermentation process in the rumen (Kumar et al., 2013). The $\mathrm{pH}$ in present study is similar among CP levels, this observation is in agreement with previous in vivo studies (Promkot and Wanapat, 2005; Chantiratikul et al., 2009; Chen et al., 2010), which reported that $\mathrm{pH}$ was not significantly affected by increasing $\mathrm{CP}$ level. The $\mathrm{pH}$ value decreased as the amount of concentrate in diet increased, which was similar to findings from Kumar et al. (2013). The $\mathrm{pH}$ values in present study were relatively stable at 6.06 to 6.77 , and were greater than the 5.0 to 5.5 range suggested by Hoover (1986) which the ruminal microbial activity was negatively affected. The numerically higher $\mathrm{NH}_{3}-\mathrm{N}$ concentration could indicate a higher rate of CP degradation (Crawford et al., 1978). Therefore, feeds in our study with higher CP levels could also have contributed to higher $\mathrm{CP}$ degradation which may have caused a greater $\mathrm{NH}_{3}-\mathrm{N}$ concentration. However, in present study no significant difference was found between $16 \%$ and $19 \% \mathrm{CP}$ in concentrate regarding $\mathrm{NH}_{3}-\mathrm{N}$ and microbial $\mathrm{CP}$ concentration. While increasing concentrate above $80 \%$ would result in $\mathrm{NH}_{3}-\mathrm{N}$ and microbial $\mathrm{CP}$ being higher as compared to other levels. Based on the results of our experiment, $16 \% \mathrm{CP}$ in concentrate and $80 \%$ concentrate in diet is recommendable.

The total VFA and molar proportion of individual VFA (acetate, propionate and butyrate) were not significantly affected by increased CP level. Some in vivo studies (Chen et al., 2010; Chanthakhoun et al., 2012; Norrapoke et al., 2012) reported that increasing $\mathrm{CP}$ had no significant effected on the VFA which was similar to our observations. Whereas, difference of roughage to concentrate ratios significantly affected total VFA production which increased linearly with the proportion of concentrate's increase. However, the proportion of individual VFA did not vary significantly with roughage to concentrate ratios, except for proportion of acetate at $24 \mathrm{~h}$ incubation. These results are in agreement with that of Suharti et al. (2011) and Kumar et al. (2013) who reported that total VFA production was significantly affected by forage to concentrate ratio in the diet, but not molar proportion of individual VFA or acetate to propionate ratio. Production of total VFA increased when the level of concentrate in the ration increased. Zicarelli et al. (2011) also found that there were no differences among ration of roughage and concentrate in molar proportion of acetate, propionate and butyrate. McDonald et al. (1995) also found that a higher fermentable carbohydrate in the diet could have led to lower level of acetate. When rumen fermentation conditions are optimal, the acetate to propionate ratio should be greater than 2.1:1 (McDonald et al., 1995). In our study, acetate to propionate ratios was within the conditions of optimal fermentation. The average of acetate, propionate and butyrate concentrations in this study were $52.6 \%-66.6 \%, 19.4 \%-25.3 \%$, and $9.2 \%-12.9 \%$ of total VFA, respectively, which is similar to those reported in several previous studies (Chumpawadee et al., 2009; Chanthakhoun et al., 2012; Norrapoke et al., 2012).

In conclusion, for concentrate mixtures with different $\mathrm{CP}$ levels, increasing $\mathrm{CP}$ levels had no significant effect on DM and $\mathrm{OM}$ digestibility, whereas $\mathrm{NH}_{3}-\mathrm{N}$ and microbial $\mathrm{CP}$ concentration were improved by increasing CP levels. However, no significant difference was found between $16 \%$ and $19 \%$ CP levels. For mixed feeds with different ratios of roughage to concentrate, in vitro DM, OM digestibility, $\mathrm{NH}_{3}-\mathrm{N}$, microbial $\mathrm{CP}$ and total VFA concentration were increased as proportion of concentrate in diet increased. These observations suggest that $16 \%$ of $\mathrm{CP}$ in concentrate and concentrate up to $80 \%$ in diet may be recommended for in vitro fermentation.

\section{REFERENCES}

Agle, M., A. N. Hristov, S. Zaman, C. Schneider, P. M. Ndegwa, and V. K. Vaddella. 2010. Effect of dietary concentrate on rumen fermentation, digestibility, and nitrogen losses in dairy cows. J. Dairy Sci. 93:4211-4222.

Association of Official Analytical Chemists (AOAC). 1990. Official Method of Analyis. 15th edn. AOAC international, Arlington, Virginia, USA. 
Bannink, A., J. Kogut, J. Dijkstra, J. France, S. Tamminga, and A. M. Van Vuuren. 2000. Modelling production and portal appearance of volatile fatty acids in dairy cows. In Modelling Nutrient Utilization in Farm Animals (Eds. J. P. McNamara, J. France, and D. E. Beever). CAB International, CABI publishing, Wallingford, UK.

Chanthakhoun, V., M. Wanapat, and J. Berg. 2012. Level of crude protein in concentrate supplements influenced rumen characteristic, microbial synthesis and digestibility in swamp buffaloes (Bubalus bubalis). Livest. Sci. 144:197-204.

Chantiratikul, A., S. Chumpawadee, W. Kanchanamayoon, and P. Chantiratikul. 2009. Effect of dietary protein on nutrient digestibility and nitrogen metabolism in Thai-Indigenous heifers. J. Anim. Vet. Adv. 8:297-300.

Chen, S., P. Paengkoum, X. Xia, and P. Na-Lumpang. 2010. Effects of dietary protein on ruminal fermentation, nitrogen utilization and crude protein maintenance in growing Thaiindigenous beef cattle fed rice straw as roughage. J. Anim. Vet. Adv. 9:2396-2400.

Chumpawadee, S., A. Chantiratikul, V. Rattanaphun, C. Prasert, and K. Koobaew. 2009. Effects of dietary crude protein levels on nutrient digestibility, ruminal fermentation and growth rate in Thai-Indigenous yearling heifers. J. Anim. Vet. Adv. 8: 1131-1136.

Crawford, R. J., W. H. Jr Hoover, C. J. Sniffen, and B. A. Crooker. 1978. Degradation of feedstuff nitrogen in the rumen vs nitrogen solubility in three rumen solvents. J. Anim. Sci. 46:1768-1775.

Getachew, G., P. H. Robinson, E. J. DePeters, and S. J. Taylor. 2004. Relationships between chemical composition, dry matter degradation and in vitro gas production of several ruminant feeds. Anim. Feed. Sci. Technol. 111:57-71.

Ghorbani, B., T. Ghoorchi, H. Amanlou, and S. Zerehdaran. 2011. Effects of using monensin and different levels of crude protein on milk production, blood metabolites and digestion of dairy cows. Asian Australas. J. Anim. Sci. 24:65-72.

Hoover, W. H. 1986. Chemical factors involved in ruminal fiber digestion. J. Dairy Sci. 69:2755-2766.

Krause, K. M. and G. R. Oetzel. 2006. Understanding and preventing subacute ruminal acidosis in dairy herds: A review. Anim. Feed Sci. Technol. 126:215-236.

Kumar, S., S. S. Dagar, S. K. Sirohi, R. C. Padhyay, and A. K. Puniya. 2013. Microbial profiles, in vitro gas production and dry matter digestibility based on various ratios of roughage to concentrate. Ann. Microb. 63:541-545.

Martin, J. S. and M. M. Martin. 1982. Tannin assays in ecological studies: Lack of correlation between phenolics, proanthocyanidins and protein-precipitating constituents in mature foliage of six oak species. Oecologia 54:205-211.

McDonald, P., R. A. Edwards, J. F. D. Greenhalgh, and C. A. Morgan. 1995. Animal Nutrition. Longman Singapore Publisher (Pte) Ltd., Singapore.

Menke, K. H. and H. Steingass. 1988. Estimation of the energetic feed value obtained from chemical analysis and gas production using rumen fluid. Anim. Res. Dev. 28:7-55.

Mills, J. A. N., J. France, and J. Dijkstra. 1999. A review of starch digestion in the lactating dairy cow and proposals for a mechanistic model: 1. Dietary starch characterisation and ruminal starch digestion. J. Anim. Feed Sci. 8:291-340.

Milis, C. and D. Liamadis. 2007. Effect of protein levels, main protein and non forage fiber source on digestibility, $\mathrm{N}$ balance energy value of sheep rations. J. Anim. Vet. Adv. 6:68-75.

Norrapoke, T., M. Wanapat, and S. Wanapat. 2012. Effects of protein level and mangosteen peel pellets (Mago-pel) in concentrate diets on rumen fermentation and milk production in lactating dairy crossbreds. Asian Australas. J. Anim. Sci. 25:971-979.

Ørskov, E. R. 1986. Starch digestion and utilization in ruminants. J. Anim. Sci. 63:1624-1633.

Paengkoum, P. and P. Tatsapong. 2009. Effect of different levels of protein on feed intake, digestibility and growth rate of Thai native beef fed pangola grass as roughages. In: Establishment of a Feeding Standard of Beef Cattle and a Feed Database for the Indochinese Peninsula (Eds. S. Oshio, M. Otsuka, and K. Sommart). JIRCAS, Tsukuba, pp. 76-78.

Pina, D. S., S. C. Valadares Filho, L. O. Tedeschi, A. M. Barbosa, and R. F. D. Valadares. 2009. Influence of different levels of concentrate and ruminally undegraded protein on digestive variables in beef heifers. J. Anim. Sci. 87:1058-1067.

Promkot, C. and M. Wanapat. 2005. Effect of level of crude protein and use of cottonseed meal in diets containing cassava chips and rice straw for lactating dairy cows. Asian Australas. J. Anim. Sci. 18:502-511.

Rodríguez, R., M. Mota, C. Castrillo, and M. Fondevila. 2010. In vitro rumen fermentation of the tropical grass Pennisetum purpureum and mixtures with browse legumes: Effects of tannin contents. J. Anim. Physiol. Nutr. 94:696-705.

Shahzad, S. A., N. A. Tauqir, F. Ahmad, M. U. Nisa, M. Sarwar, and M. A. Tipu. 2011. Effect of feeding different dietary protein and energy levels on the performance of 12-15-month old buffalo calves. Trop. Anim. Health Prod. 43:685-694.

Soltan, Y. A., A. S. Morsy, S. M. A. Sallam, H. Louvandini, and A. L. Abdalla. 2012. Comparative in vitro evaluation of forage legumes (prosopis, acacia, atriplex, and leucaena) on ruminal fermentation and methanogenesis. J. Anim. Feed. Sci. 21:759772.

Suharti, S., D. A. Astuti, E. Wina, and T. Toharmat. 2011. Rumen microbial population in the in vitro fermentation of different ratios of forage and concentrate in the presence of whole lerak (Sapindus rarak) fruit extract. Asian Australas. J. Anim. Sci. 24:1086-1091.

Tagliapietra, F., M. Cattani, H. H. Hansen, I. K. Hindrichsen, L. Bailoni, and S. Schiavon. 2011. Metabolizable energy content of feeds based on 24 or $48 \mathrm{~h}$ in situ NDF digestibility and on in vitro $24 \mathrm{~h}$ gas production methods. Anim. Feed Sci. Technol. 170:182-191

Tahir, M. N., M. Hettaa, M. Larsen, P. Lund, and P. Huhtanena. 2013. In vitro estimations of the rate and extent of ruminal digestion of starch-rich feed fractions compared to in vivo data. Anim. Feed Sci. Technol. 179:36-45.

Thang, C. M., I. Ledin, and J. Bertilsson. 2011. Degradation characteristics and fermentation kinetics of some tropical legumes and cassava foliage/root determined by the in vitro gas production technique. J. Anim. Sci. Technol. 29:40-53.

Theodorou, M. K., B. A. Williams, M. S. Dhanoa, A. B. McAllan, and J. France. 1994. A sample gas production method using a 
pressure transducer to determine the fermentation kinetics of ruminant feeds. Anim. Feed Sci. Technol. 48:185-197.

Van Soest, P. J., J. B. Robertson, and B. A. Lewis. 1991. Method for dietary fiber, neutral detergent fiber and non-starch polysaccharide in relation to animal nutrition. J. Dairy Sci. 74: 3583-3597.
Yuangklang, C., K. Vasupen, S. Wongsuthavas, and S. Bureenok. 2010. Effect of protein level on nutrient digestibility and nitrogen utilization in beef cattle. J. Anim. Vet. Adv. 9:17761779.

Zicarelli, F., S. Calabrò, M. I. Cutrignelli, F. Infascelli, R. Tudisco, F. Bovera, and V. Piccolo. 2011. In vitro fermentation characteristics of diets with different forage/concentrate ratios: comparison of rumen and faecal inocula. J. Sci. Food. Agric. 91:1213-1221. 